\title{
POPULAȚIA ROMÂNIEI ÎN ULTIMUL SECOL - ÎN CIFRE ȘI IMAGINI
}

Corina-Georgeta DINCULESCU ${ }^{\odot}$, cercetător științific, Institutul de Economie Agrară, România

DOI: https://doi.org/10.36004/nier.cdr.2019.14-01 JEL Classification: J10, J11, J14, J16, R10, R23.

Din cele mai vechi timpuri, oamenii au realizat cercetări statistice, observaţii şi estimări care $i$-au ajutat să-şi organizeze viaţa. Pe teritoriul tării noastre, există o îndelungă şi bogată tradiţie în domeniul evidenţei şi statisticii, referindu-se la numărul locuitorilor, suprafeţe, producția principalelor culturi, numărul animalelor domestice etc. Recensămintele populaţiei se numără printre cele mai complexe și masive cercetări statistice, ale căror date sunt esențiale pentru buna guvernare a unei ţări, pentru planificarea dezvoltării, pornind de la diverse strategii realizate pe baza acestor date, analize în diferite domenii.

De-a lungul timpului, statistica din România s-a dezvoltat, anul 1859 fiind cel care a marcat crearea statisticii oficiale din România. $O$ dată cu aceasta, $s$-a realizat primul recensământ al populaţiei, atât de necesar pentru realizarea unei imagini cât mai cuprinzătoare a realităţilor tării.

Această lucrare îşsi propune o scurtă descriere a evoluției populației şi a structurii acesteia, în ultimul secol, pe diferite caracteristici demografice şi economico-sociale, atât la nivel național, cât şi pe medii de rezidență, funcție de disponibilitatea datelor. Referirea la ultimul secol este dată de documentarea asupra istoriei recensămintelor realizate după Marea Unire, prin evidențierea recensămintelor ultimului secol din România - cele zece recensăminte ale populației (şi ale locuințelor, unele dintre ele), din 1912, 1930, 1941, 1948, 1956, 1966, 1977, 1992, 2002, 2011.

De asemenea, punerea în prim plan a mediului rural, dinamica populației rurale $\hat{i}$ intervalul de timp amintit, poziționarea populației rurale față de cea din mediul urban sunt alte câteva dintre obiectivele acestei lucrări. sex, vârstă.

Cuvinte-cheie: recensământ al populației, populație, rural, urban, tendințe demografice,

Since ancient times, people have done statistical research, observations and estimates that helped them organize their lives. In our country, there is a long and rich tradition in the field of records and statistics, referring to the number of inhabitants, areas, the production of the main crops, the number of domestic animals, etc. Population censuses are among the most complex and massive statistical surveys, the data of which are essential for the good governance of a country, for development planning, starting from various strategies based on these data, analyzes in different fields.

Over time, the statistics in Romania developed, the year 1859 being the one that marked the foundation of official statistics in Romania. With this, the first census of the population was carried out, so necessary to achieve a more comprehensive picture of the realities of the country.

This paper proposes a brief description of the evolution of the population and its structure, in the last century, on different demographic and economic-social characteristics, both at national level and at residence, depending on the availability of data. The reference to the last century is given by the documentation on the history of the censuses made after the Great Union, by highlighting the censuses of the last century in Romania - the ten census of the population (and of the dwellings, some of them), from 1912, 1930, 1941, 1948, 1956, 1966, 1977, 1992, 2002, 2011.

Also, putting in the foreground of the rural environment, the dynamics of the rural population within the mentioned time interval, the positioning of the rural population with respect to the urban one are some of the other objectives of this work.

\footnotetext{
${ }^{\circledR}$ Corina-Georgeta Dinculescu, corina.dinculescu@gmail.com
} 
Keywords: population census, population, rural, urban, demographic trends, sex, age.

Privind din prezent, înapoi, spre începutul secolului, vom pune în prim plan, prin cifre şi imagini, evoluţia populaţiei şi modificările structurale intervenite în această perioadă, sub influența unor factori de ordin politic, social, economic, psihologic, educativ şi legislativ. Vor fi evidenţiaţi indicatori specifici (demografici, socio-economici), semnificativi, care vor marca tendințe și evoluții.

\section{Densitatea populaţiei ${ }^{1}$}

Modificările suprafeţei României, precum şi cele ale populaţiei, au influenţat densitatea populaţiei. De-a lungul timpului, România s-a situat în rândul ţărilor cu densitate medie (între 10100 locuitori $/ \mathrm{km}^{2}$ ). Totuşi nivelul acestui indicator s-a modificat, în sensul creşterii continue a densităţii populaţiei, astfel că datele ultimelor recensăminte $(1977,1992,2002$ şi 2011) relevă o densitate a populaţiei aflată la limita superioară a intervalului de încadrare în grupa densităţii medii. Dacă în intervalul 1918 - 1992 densitatea populaţiei a crescut continuu, din 1992 până astăzi, acest indicator a fost în scădere.

Evoluţia demografică din România se înscrie într-un trend regional similar întâlnit şi în ţări apropriate (Bulgaria, Ucraina, Serbia, Croaţia şi în Bosnia Herțegovina ${ }^{2}$.

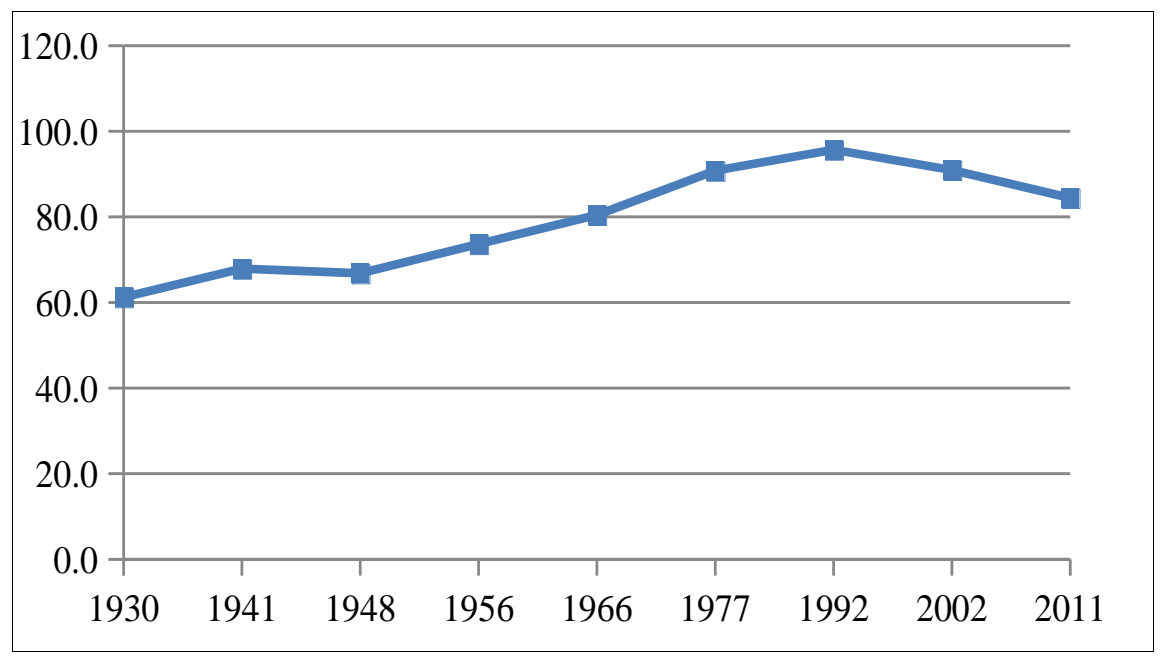

Figura 1. Densitatea populaţiei, în perioada 1930 - 2011

Sursa: Volumele recensămintelor populaţiei din anii 1930, 1948 1956, 1966, 1977, 1992, 2002, 2011

\section{Populaţia}

După înfăptuirea Marii Uniri, populaţia României Mari ajunsese la 18 milioane de locuitori (conform datelor de la recensământul populaţiei din anul 1930), iar după un secol, datele ultimului recensământ evidenţiază o populaţie de 20 milioane de locuitori. Potrivit datelor recensămintelor, populaţia României a crescut continuu începând cu 1948, până în anul 1992, inclusiv. După acest an, populaţia s-a aflat pe un trend continuu descrescător, din cauza sporului natural negativ şi a fenomenului de emigrare, din ce în ce mai intens, mai ales după aderarea României la UE. Cu o populaţie de 19,6 milioane de locuitori în 2017, România va ajunge la 16,43 milioane de locuitori în anul 2050, la un nivel asemănător recensământului din 1948.

\footnotetext{
${ }^{1}$ Densitatea populaţiei reprezintă numărul de locuitori pe unitate de suprafaţă, măsurându-se, în general, în locuitori pe kilometru pătrat, şi se obține prin împărțirea numărului de locuitori la suprafață (exprimată în kilometri pătrați).

2 potrivit datelelor Băncii Mondiale.

${ }^{3}$ Aşa cum arată datele ONU, care prevede un viitor sumbru al ţării noastre, inclusă în top 10 al statelor al căror număr de locuitori va scădea cu peste $15 \%$.
} 


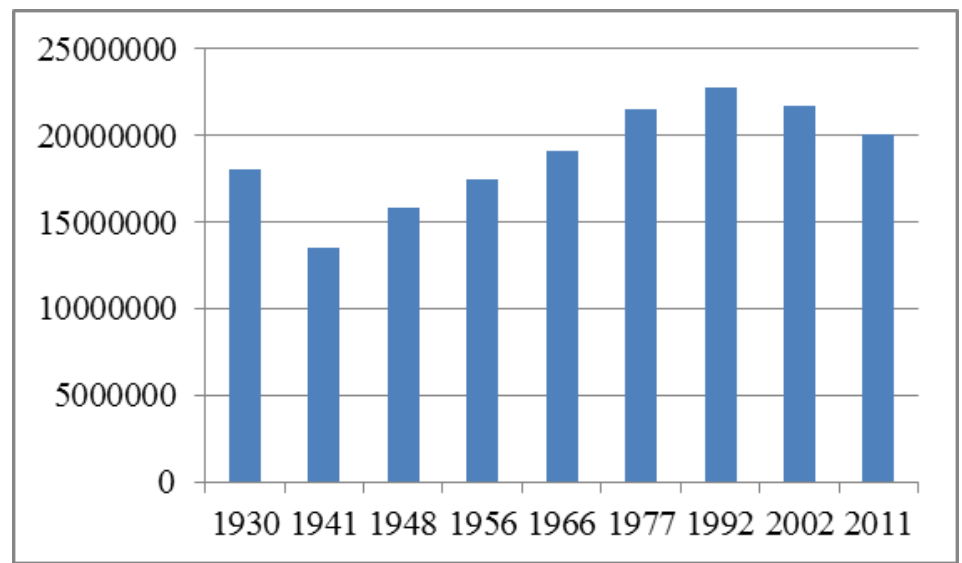

Figura 2. Populaţia României, la recensămintele din perioada 1930 - 2011

Sursa: Volumele recensămintelor populaţiei din anii 1930, 1941, 1948, 1956, 1966, 1977, 1992, 2002, 2011

După o creștere semnificativă, începând cu 1948, de aproximativ șapte milioane de locuitori (până în 1992), recensământul din 7 ianuarie 1992 a fost cel care a marcat un record în ceea ce priveşte nivelul populaţiei României - 22,8 milioane de persoane Aceasta s-a datorat acumulării fenomenelor demografice existente încă din perioada comunistă.

După evenimentele din 1989, au fost abrogate decretele privind: avortul, divorțurile, interdicția persoanelor de a se stabili in marile orașe, s-au "deschis" graniţele, cu efectele imediate asupra populaţiei: creșterea îngrijorătoare a avorturilor, suprapopularea marilor orașe, emigrația din anii imediat următori revoluţiei din 1989.

După aproape o jumătate de secol (neluând în considerare recensământul din 1941, de la care a început, de fapt, tendinţa de creştere a populaţiei, dar care a fost marcat de evenimente politice ale vremii care și-au pus amprenta asupra nivelului populației, dar în mod artificial), la recensământul din 2002, populația României a înregistrat prima scădere, până la 21,7 milioane de locuitori, urmată de cea înregistrată la recensământul din 2011, când populația României a numărat 20,1 milioane de locuitori.

Trendul descrescător (cel dintre recensămintele din anii 1930 şi 1941 şi cel înregistrat după recensământul din 1992) se explică prin faptul că, după 1918, România a pierdut teritorii (Basarabia - 2,9 milioane locuitori, iar Bucovina - 853 mii locuitori, potrivit datelor recensământului din 1930) și a suferit mai multe valuri de migrație: pe de o parte, etnici maghiari care au plecat imediat după Marea Unire şi etnici germani care au fost "vânduți" în perioada comunismului sau au emigrat imediat după schimbările politice din decembrie 1989 şi pe de altă parte, migraţia masivă, în special, în ultimii 10-15 ani, pentru a muncii în special în Europa de Vest, dar şi în alte ţări. Toate aceste plecări au schimbat profilul demografic și cultural al țării.

\section{Structura populației pe sexe}

În întreaga perioadă a celor 100 de ani se constată o structură pe sexe echilibrată, cu o uşoară predominare a populaţiei feminine atât la nivel naţional, cât şi pe medii de rezidenţă (ponderea populaţiei feminine s-a situat mereu în jurul valorii de $51 \%$, iar populaţia masculină 49\%, cu mici fluctuaţii în întreaga perioadă).

\section{Structura populaţiei pe medii de rezidenţă}

La începutul celor 100 ani, repartizarea demografică după medii de rezidență evidenţiază faptul că populaţia României trăia în mare parte în mediul rural, astfel că datele recensământului din 1930 relevă o proporţie a populaţiei rurale de 79,8\% (în timp ce în mediul urban trăiau doar 20.2\%), iar la recensământul anterior - 1912, 81,6\% dintre persoane trăiau în mediul rural şi numai 18,3\% persoane, în orașe şi comune suburbane care aparțineau oraşelor. Valorile date de cele două recensăminte ne ajută să poziţionăm populaţia rurală şi pe cea urbană existentă la începutul 
secolului XX. Ponderea mare a populaţiei rurale s-a datorat, în special, ratei de natalitate mai ridicată în comunele rurale, cum erau denumite atunci.

Tendinţa înregistrată de populația rurală a fost una ascendentă, începând din 1948 până în 1966, când aceasta s-a inversat, ponderea populaţiei rurale începând să scadă de la un recensământ la altul, astfel că la ultimul recensământ, din 2011, a ajuns la 46\% din totalul populaţiei.

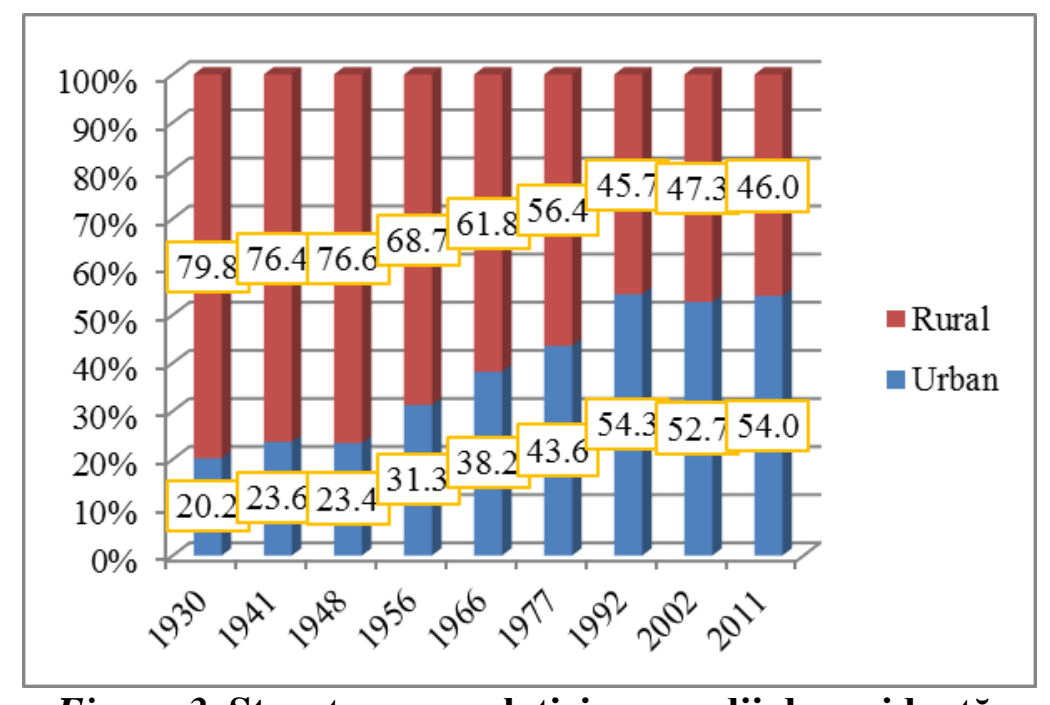

Figura 3. Structura populaţiei, pe medii de rezidenţă, la recensămintele din perioada 1930 - 2011

Sursa: Volumele recensămintelor populației din anii 1930, 1941, 1948, 1956, 1966, 1977, 1992, 2002, 2011

În anul 1956, populația din mediul rural a rămas aproximativ constantă, creșterea populației totale bazându-se pe populaţia din mediul urban, care faţă de recensământul anterior a înregistrat o creştere de 1,761 milioane persoane, adică o creștere a ponderii populaţiei rurale cu 7,9 pp.

Începând cu 1966, aşa cum a fost precizat anterior, populația de la sate a început să scadă, iar cea urbană să crească, atât în valori absolute, cât şi în valori relative, iar în 1977, deşi populaţia rurală a crescut (în cifre absolute), ponderea acesteia în populația totală a scăzut cu 5,4 pp. Aceasta se explică printr-o creştere a populaţiei totale, pe seama populaţiei urbane cu aproape 2 milioane persoane (creştere mult mai mare decât cea din mediul rural (a cărei creştere a fost doar puţin peste jumătate de milion de persoane). Recensământul din 1977 a fost ultimul în care populaţia din mediul rural o depăşea pe cea din mediul urban.

Tendinţa de scădere a populaţiei, atât la nivel naţional, cât şi în mediul rural, începută în 1977, a continuat şi la recensămintele următoare, iar populaţia urbană a crescut până în 1992, iar după acest an, a intrat şi aceasta pe trendul înregistrat de populaţia naţională şi de cea rurală.

Recensământul din 2011 evidenţiază cea mai redusă populaţie rurală din întreaga perioadă a celor 100 ani şi cel mai scăzut nivel al populaţiei din mediul urban de după revoluție.

Tabel 1. Rate de creștere a populaţiei totale, rurale şi urbane, în perioada 1930 - 2011

\begin{tabular}{|l|c|c|c|c|c|c|c|c|}
\hline TOTAL & $\mathbf{1 9 4 1 - 1 9 3 0}$ & $\mathbf{1 9 4 8 - 1 9 4 1}$ & $\mathbf{1 9 5 6 - 1 9 4 8}$ & $\mathbf{1 9 6 6 - 1 9 5 6}$ & $\mathbf{1 9 7 7 - 1 9 6 6}$ & $\mathbf{1 9 9 2 - 1 9 7 7}$ & $\mathbf{2 0 0 2 - 1 9 9 2}$ & $\mathbf{2 0 1 1 - 2 0 0 2}$ \\
\hline URBAN & 24.4 & -1.0 & 7.9 & 7.8 & 4.5 & 10.7 & -1.6 & 1.2 \\
\hline RURAL & 75.6 & 1.0 & -7.9 & -7.8 & -4.5 & -10.7 & 1.6 & -1.2 \\
\hline
\end{tabular}

Sursa: Calcule proprii, după date extrase din volumele recensămintelor populaţiei din anii 1930, 1941, 1948, 1956, 1966, 1977, 1992, 2002, 2011

Tendinţele enunţate în cei 100 de ani analizaţi sunt relevaţi şi prin datele tabelului de mai sus - intensitatea scăderii, respectiv a creşterii populaţiei rurale, şi a celei urbane, diferă de la perioadă la perioadă. Conform datelor din tabel, cea mai rapidă urbanizare a avut loc în perioada 
1992-1977 (neluând în calcul perioada în care există cea mai mare valoare a acestui indicator 19411930, din considerente care ţin de modificarea graniţelor/suprafeţei ţării, precum şi de metodologia de împărţire a populaţiei, pe medii, din acea perioadă). Această concluzie este confirmată de o populaţie urbană mai ridicată din 1992 faţă de 1977, ca urmare a schimbărilor legislative cu privire la interdicţia persoanelor de a se stabili în marile oraşe în perioada anterioară evenimentelor politice din decembrie 1989.

\section{Structura populației pe vârste}

La începutul secolului XX, România era o țară cu o populaţie foarte tânără - ponderea populaţiei de 0-15 ani, de 40,1\%, fiind depăşită doar de Serbia (cu 41,9\%). Totodată, în clasamentul ţărilor din Europa, avea cea mai mică pondere a populaţiei de peste 60 de ani în total populaţie $(7,7 \%)$.

După Marea Unire, potrivit datelor recensământului din 1930, aproximativ 7,7\% din populaţia României avea peste 60 de ani. Datele ultimului recensământ relevă o pondere a populaţiei de 60 ani şi peste de $22,3 \%$ din totalul populaţiei, evidenţiind o populaţie din ce în ce mai îmbătrânită. Aceasta are un impact major asupra dezvoltării unei populaţii echilibrate, ceea ce se va resimţi asupra ocupării populaţiei. De asemenea, o populaţie îmbătrânită are consecinţe majore asupra politicilor sociale privind securizarea sistemului de pensii şi asupra sectorului de sănătate.

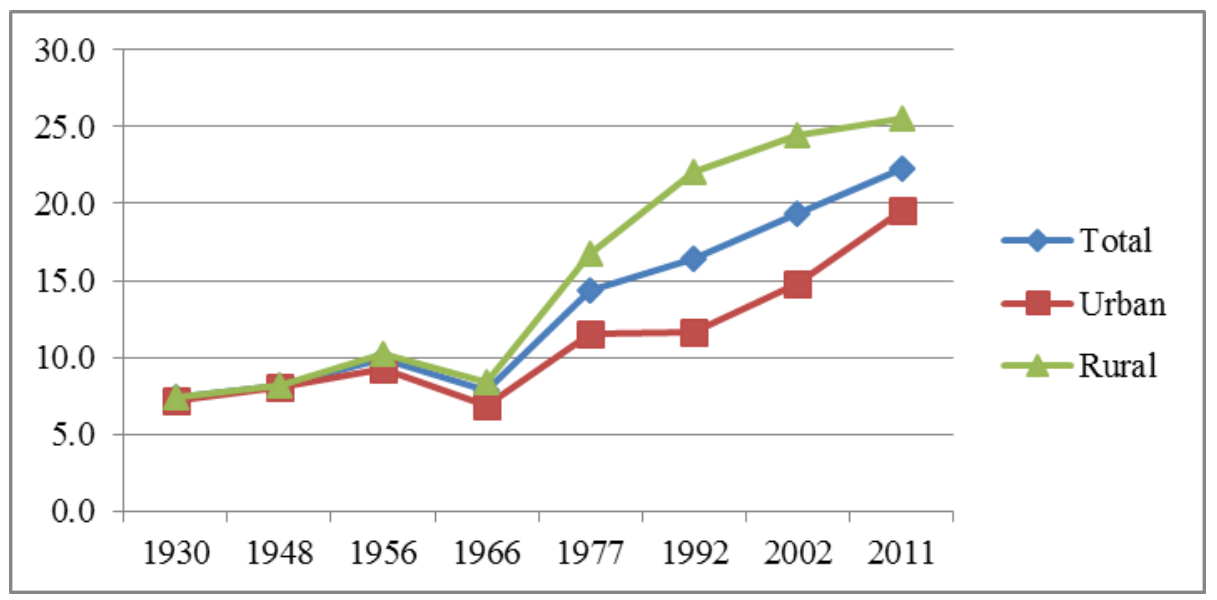

Figura 4. Ponderea populaţiei de 60 ani şi peste, la recensămintele din perioada 1930 - 2011 Sursa: Volumele recensămintelor populaţiei din anii 1930, 1948, 1956, 1966, 1977, 1992, 2002, 2011

De asemenea, o populaţie îmbătrânită are consecinţe majore asupra politicilor sociale privind securizarea sistemului de pensii şi asupra sectorului de sănătate.

În mediul rural, situaţia este şi mai nefavorabilă, dacă la începutul celor 100 de ani, datele recensămintelor din 1930 şi 1948 (şi chiar următoarele două) au arătat o pondere a populaţiei 60 ani şi peste de $7,4 \%$, respectiv $8,2 \%$, asemănătoare la nivel naţional şi pe cele două medii de rezidenţă. În timp, situaţia s-a schimbat, în defavoarea populaţiei de 60 ani şi peste din mediul rural. Aceasta a crescut de la un recensământ la altul, iar ecartul dintre mediul rural şi nivelul naţional a fost tot mai mare. Ecartul dintre mediul rural şi mediul urban, în ceea ce priveşte ponderea populaţiei de 60 ani şi peste, a devenit din ce în ce mai mare după 1966. Practic, ponderea persoanelor de 60 ani şi peste din mediul rural excede pe cea din mediul urban, de la un recensământ la altul. Maximul de excedent al populaţiei rurale de 60 ani și peste a fost consemnat de datele recensămintelor din 1992 şi 2002, când ponderea populaţiei rurale de 60 ani şi peste a fost aproape dublă faţă de cea din mediul urban.

Datele ultimului recensământ confirmă tendinţa de continuă creştere a ponderii populaţiei de 60 ani şi peste, atât la nivel naţional, cât şi pe medii de rezidenţă, semnalând faptul că peste un sfert din populaţia rurală face parte din grupa de vârstă 60 ani şi peste. 


\section{Instruirea populației}

Nivelul de educaţie este un element important în aprecierea gradului de civilizaţie a unui popor. Unul dintre cei mai importanţi indicatori ai educaţiei se referă la persoanele alfabete (ştiutoare de carte). Conform recensământului general din 1930, numărul analfabeților era de 6,2 milioane, mai numeroase fiind femeile (aproape două treimi din totalul analfabeţilor fiind femei). Pe medii de rezidenţă, se evidenţiază o pondere covârşitoare a analfabeţilor din mediul rural (88,5\%), două treimi dintre aceștia fiind femei. De altfel, atât la nivel naţional, cat şi în mediul urban se observă că din totalul analfabeților, două treimi sunt femei.

Repartiția analfabeților pe sexe şi medii de rezidenţă relevă o constanţă (negativă, de altfel) în ceea ce privește ponderea femeilor în totalul analfabeților, în întreaga perioadă analizată. De asemenea, ruralul deține ponderea majoritară, covârșitoare chiar, în totalul analfabeților. Un an de cotitură a fost 1977, când tendința de creștere a ponderii femeilor analfabete în totalul analfabeților s-a inversat, după acest an, acesta începând sa se diminueze până în prezent (ultimul recensământ). Paralel cu aceasta, trendul descrescător al ponderii bărbaţilor analfabeți în totalul analfabeților, înregistrat până în 1977, s-a inversat, astfel ca la ultimul recensământ, acesta pondere a crescut considerabil.

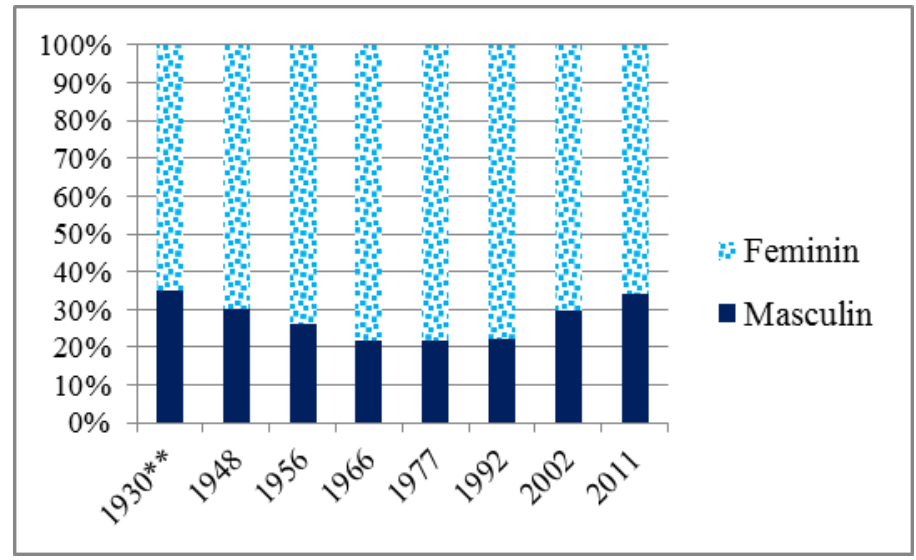

Figura 5. Structura analfabeților, pe sexe, la recensămintele din perioada 1930 - 2011

Sursa: Volumele recensămintelor populaţiei din anii 1930, 1948, 1956, 1966, 1977, 1992, 2002, 2011

Pe medii de rezidenţă, trendul pe perioada analizată este aproximativ același, cea mai mare pondere a analfabeților este deținută de femei, atât la nivel național, cât şi pe medii de rezidenţă.

\section{Etnie}

În România au trăit de-a lungul timpului, alături de comunitatea românească, diferite comunităţi etnice, cu tradiții culturale, lingvistice și religioase specifice.

Problemele organizării lumii după primul război mondial au constituit obiectul Conferinței de Pace de la Paris (1919-1920). Aceasta a pus la baza deciziilor sale principiul naționalităților. S-a avut în vedere ca noile granițe europene să includă în interiorul fiecărui stat un număr cât mai mic de minorităţi, dar acest lucru nu s-a putut realiza pe deplin, nefiind posibilă o departajare statală pe criterii etnice. Practic, nu exista ţară fără minorităţi naţionale.

În Romania - potrivit datelor recensământului din 1930 - populația totală era de 18,057 milioane locuitori, dintre care: romani - $71,9 \%$, unguri $-7,9 \%$, germani $-4,1 \%$, evrei - 4\%, ţigani $1,5 \%$ și alte neamuri, cu procente mai mici. Aceste date evidenţiază ponderea minoritarilor naționale ${ }^{4}$, care, în total, era de $28,1 \%$. De-a lungul timpului, datorită unor factori care ţin de migraţiile masive desfăşurate în cei 100 de ani, a fenomenelor care conturează tabloul demografic specific fiecărei

\footnotetext{
${ }^{4}$ Totalitatea persoanelor de altă etnie decât cea a românilor.
} 
perioade, ponderea minorităţilor naţionale în totalul populaţiei s-a modificat, în sensul diminuării, datele ultimului recensământ relevând o pondere a minorităţilor naţionale de $16,5 \%$.

Pe medii de rezidenţă situaţia se prezintă astfel: în 1930, ponderea minorităţilor naţionale din mediul rural a fost de $24,7 \%$, iar la ultimul recensământ această pondere s-a diminuat, ajungând la $15,6 \%$ (situaţie similară celei constatate la nivel naţional). De asemenea, ponderea minorităţilor naţionale mediul urban, a scăzut la mai puţin de jumătate faţă de nivelul anului 1930 - de la 41,4\%, în 1930 la 17,4\% în 2011.

Atât la nivel naţional, cât şi pe medii de rezidenţă, în întreaga perioadă analizată, se observă variații ale acestui indicator.

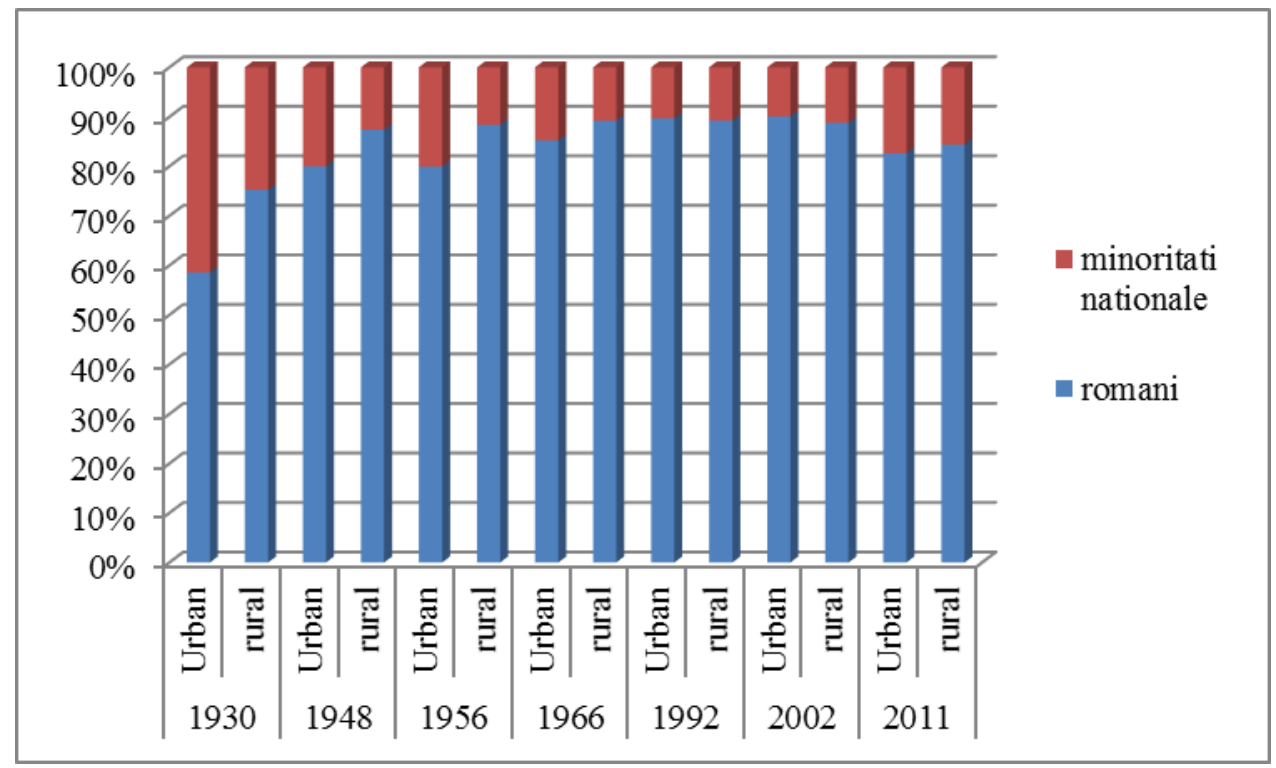

Figura 6. Ponderea minorităților naţionale, pe medii de rezidenţă, la recensămintele din perioada 1930 - 2011

Sursa: Volumele recensămintelor populaţiei din anii 1930, 19485, 1956, 1966, 1992, 2002 şi $2011^{6}$

Graficul următor evidenţiază, vizual, elemente semnificative cu privire la populaţia pe etnii, în ultimul secol:

- ponderea etnicilor români a crescut de la 71,9\% la 83,5\% (la recensămintele din anii 1992 şi 2002, aceasta ajunsese la 89,5\%);

- scăderea drastică a numărului şi ponderii etnicilor germani (de la 4,1\% în 1930 la 0,2\% în 2011) - datele recensământului din 1948 relevă o pondere de două ori mai mică decât cea din 1930, pondere care a rămas constantă la următoarele două recensăminte, după care a început să scadă, aproape că nu mai există germani în prezent;

- numărul țiganilor a crescut de două ori şi jumătate, în timp ce ponderea lor în totalul populaţiei s-a dublat;

- etnicii evrei au cunoscut aceeaşi evoluţie, ca şi germanii - în 1948, ponderea evreilor in totalul populaţiei a fost de patru ori mai mică decât în 1930, iar la recensămintele următoare aceasta a scăzut continuu, astfel că după 1992, ponderea evreilor în populaţie este zero, deşi in cifre absolute mai existau 3271 de evrei în 2011;

- ungurii/maghiarii au avut o evoluţie ascendentă până în 1956 (de la 7,9\% în 1930, 1a 9,1\%,), când ponderea lor a intrat pe un trend continuu descrescător (ajungând în 2011 la 6,1\%).

\footnotetext{
${ }^{5}$ Datele se referă la limba maternă, cele privind neamurile, nefiind disponibile.

${ }^{6}$ Pentru 1977, date privind etnia pe medii de rezidenţă nu au fost disponibile.
} 


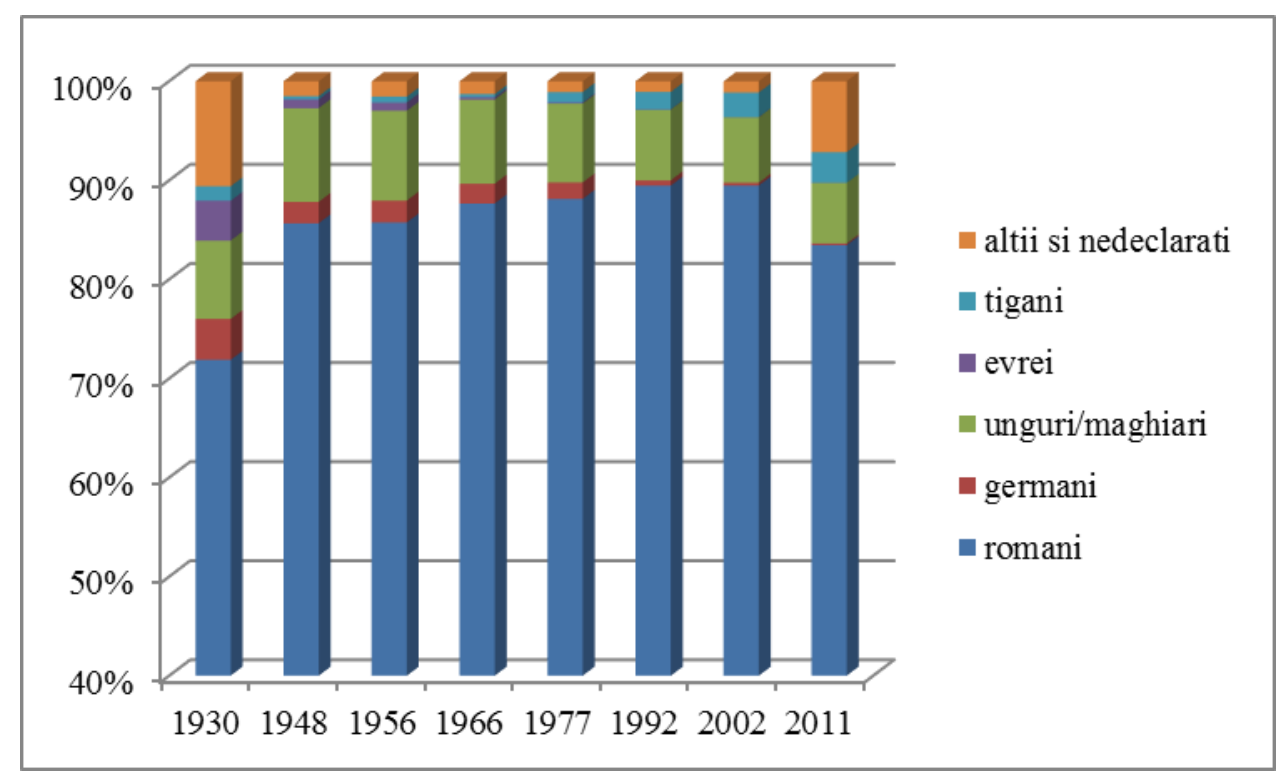

Figura 7. Ponderea minorităților naţionale, la recensămintele din perioada 1930 - 2011 Sursa: Volumele recensămintelor populaţiei din anii 1930, 19487 , 1956, 1966, 1992, 2002 şi 2011

Structura populaţiei după etnii, pe medii de rezidenţă, evidenţiază aceleaşi tendinţe semnalate la nivel naţional, dar cu particularităţi ale etniilor între cele două medii de rezidenţă, astfel că:

- creșterea ponderii românilor, remarcată la nivel naţional, s-a realizat pe seama creşterii ponderii românilor din mediul urban (creşterea a fost de 24 pp în mediul urban şi de doar 9.1 pp în mediul rural);

- etnicii germani şi evrei, din urban şi din rural se încadrează pe aceleaşi trenduri, puternic descendente, menţionate la nivelul naţional;

- scăderea ponderii ungurilor/maghiarilor a fost mai accentuată în mediul urban decât în mediul rural, în urban aceasta înjumătăţindu-se în intervalul celor 100 de ani analizaţi (în timp ce in rural, aceasta a fost mai moderată);

- etnicii ţigani au înregistrat o creştere mai accentuată a ponderii lor în totalul populaţiei din mediul rural, unde aceasta s-a triplat faţă de 1930 (în mediul urban, aceasta s-a dublat "doar").

URBAN

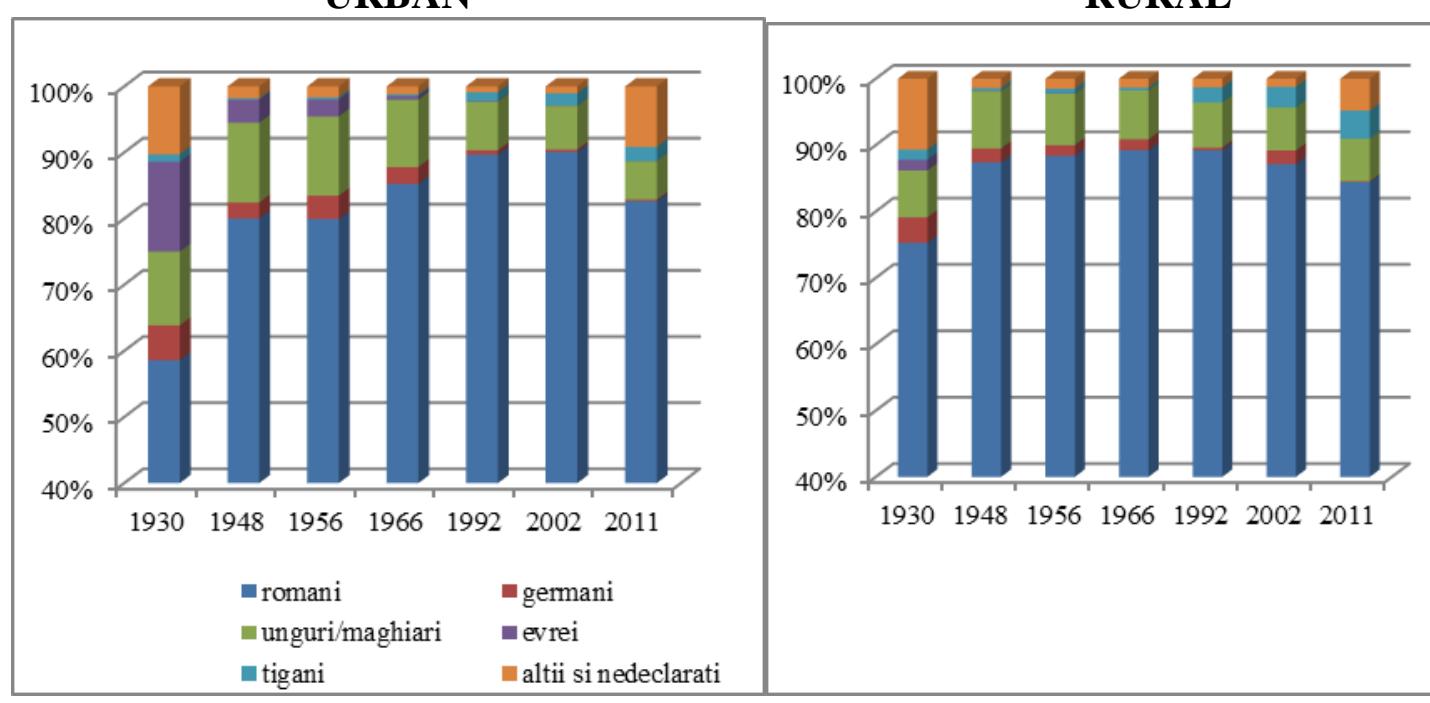

Figura 8. Structura populaţiei, pe etnii şi medii de rezidenţă,

la recensămintele din perioada 1930 - 2011

Sursa: Volumele recensămintelor populaţiei din anii 1930, 1948 , 1956, 1966, 1992, 2002 şi 2011

${ }^{7}$ Datele se referă la limba maternă, cele privind neamurile, nefiind disponibile. 


\section{Statutul economic al populaţiei}

Unul dintre indicatorii forţei de muncă este populaţia activă, care cuprinde toate persoanele ${ }^{9}$, apte de muncă şi care într-o anumită perioadă de referință reprezintă forța de munca disponibilă (utilizată sau neutilizată) pentru producerea de bunuri şi servicii în cadrul economiei naționale.

La începutul secolului analizat, populaţia activă era de 10,457 milioane persoane, reprezentând 57,9\% din totalul populaţiei. În timp, deşi populaţia totală a crescut, atingând maximul istoric de 22,810 milioane persoane la recensământul din 1992, populaţia activă a crescut doar până la recensământul din 1977 (ca număr absolut, dar nu şi ca pondere în totalul populaţiei), după care a intrat pe trendul descendent înregistrat de populația totală.

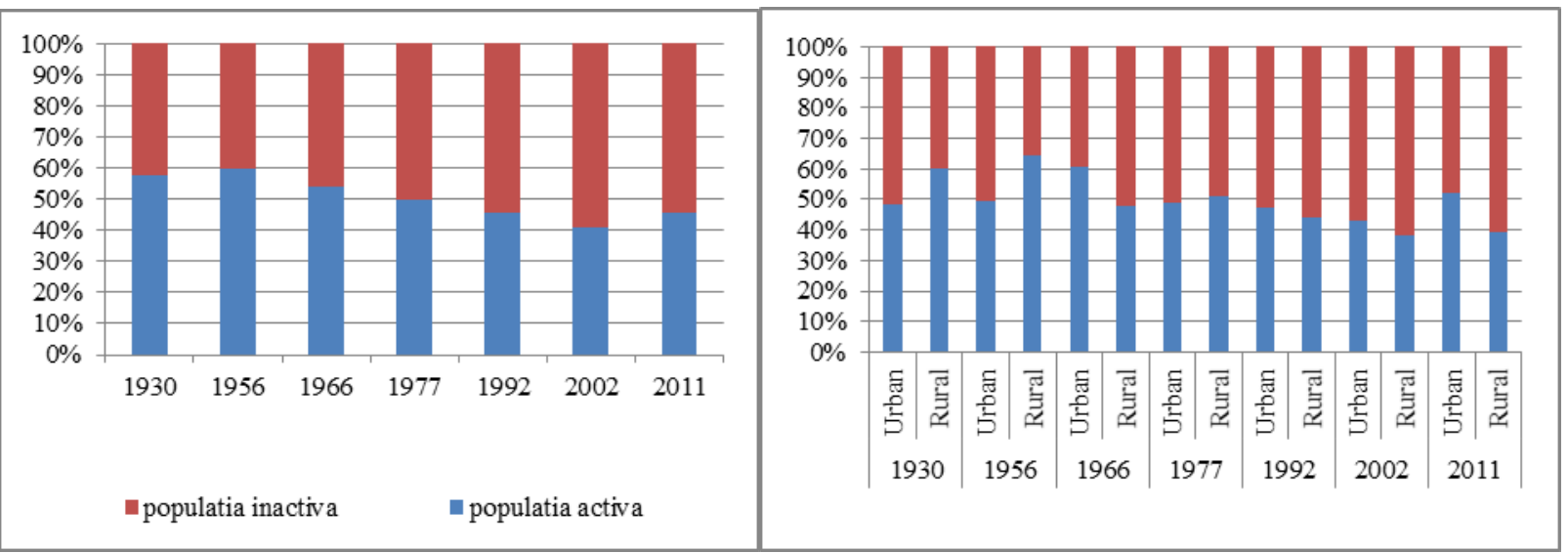

Figura 9. Structura populaţiei, după statut economic, la nivel național și pe medii de rezidență Sursa: Volumele recensămintelor populaţiei din anii 1930, 1956, 1966, 1977, 1992, 2002 şi 2011

Datorită faptului că la începutul secolului analizat populaţia era concentrată la sate în proporţie covârşitoare, structura pe medii de rezidenţă a populaţiei după statutul economic (populaţie activă şi populație inactivă) relevă o rată de activitate (raportul dintre populaţia activă şi cea totală) mai ridicată în mediul rural decât în mediul urban.

Mediul rural este caracterizat printr-o fluctuaţie continuă a ratei de activitate a populaţiei, de la un recensământ la altul, astfel că între recensăminte s-a constatat când creşteri, când scăderi ale ratei de activitate a populaţiei rurale. Rata de activitate a populaţiei urbane a urmat o traiectorie asemănătoare cu ce a populaţiei totale, cu creşteri şi scăderi la intervale largi de timp, nu între fiecare două recensăminte, ceea ce arată o stabilitate în ceea ce priveşte participarea la activitatea economică a populației urbane.

\section{Concluzii}

După o sută de ani, putem spune că dacă, imediat după Marea Unire, România era o țară tânără, după o sută de ani, profilul demografic actual al României, asemănător cu cel al ţărilor din Uniunea Europeană, este caracterizat printr-o populaţie îmbătrânită, cu dezechilibre accentuate între grupele de vârstă. Migrațiile au avut o relevanță majoră în evoluția populației României - valurile de plecări au schimbat portretul demografic și cultural al țării și au frânat sever dezvoltarea multor localităţi din țară.

Structura populației pe medii de rezidentă (urban, rural) s-a modificat, de-a lungul timpului, funcție de situația economică și politică a perioadei respective. Astfel că tendinţele enunţate în cei 100 de ani analizaţi - intensitatea scăderii, respectiv a creşterii populaţiei rurale, şi a celei urbane diferă de la perioadă la perioadă. Cea mai rapidă urbanizare a avut loc în perioada 1992-1977, ca

\footnotetext{
8 Datele se referă la limba maternă, cele privind neamurile, nefiind disponibile.

${ }^{9}$ Vârsta minimă de includere în categoria populaţiei active a diferit de-a lungul timpului.
} 
urmare a schimbărilor legislative cu privire la interdicţia persoanelor de a se stabili în marile oraşe în perioada anterioară evenimentelor politice din decembrie 1989.

\section{Bibliografie}

1. Recensămintele populaţiei - volumele tematice, specifice fiecărui an - 1912, 1930, 1941, 1948, 1956, 1966, 1977, 1992, 2002.

2. Regulamentul (CE) nr. 763/2008 al Parlamentului European și al Consiliului din 9 iulie 2008, privind recensământul populației și al locuințelor.

3. Regulamentul (CE) nr. 1201/2009 al Parlamentului European şi al Consiliului privind Recensământul Populaţiei şi al Locuinţelor, publicat în JOL 329 din 15.12.2009.

4. Regulamentul (CE) nr. 519/2010 al Parlamentului European şi al Consiliului privind Recensământul Populaţiei şi al Locuinţelor, publicat în JOL 151 din 17.06.2010.

5. Regulamentul (CE) nr. 1151/2010 al Parlamentului European şi al Consiliului privind Recensământul Populaţiei şi al Locuinţelor, privind recensământul populaţiei și al locuinţelor în ceea ce privește modalitățile și structura rapoartelor de calitate precum și a formatului tehnic pentru transmiterea datelor, publicat în JOL 324 din 9.12.2010.

6. Principles and Recommendations for Population and Housing Censuses: the 2020 Round, 2010 round, 2000 round.

7. United Nations. Principles and Recommendations for Population and Housing Censuses: the 2020 Round, 2010 round, 2000 round.

8. Monografia recensământului populaţiei şi al locuinţelor, 18 martie 2002.

9. Recensămintele populaţiei şi ale locuinţelor în România, 1899 - 2002.

10. Anuar statistic al României, 1915-1916, 1922, 1939-1940, 2017.

11. Eurostat, http://epp.eurostat.ec.europa.eu.

12. Institutul Naţional de Statistică. Recensământul Populaţiei şi al LocuinţelorRecensământul Populaţiei şi al Locuinţelor. Rezultate. http://www.recensamantromania.ro/rezultate-2/.

13. IPUMS International. https://international.ipums.org/international/.

14. Institutul Naţional de Statistică (INS). www.insse.ro. 